\title{
The Relationship between the Conscientiousness Trait and Use of the English Language Learning Strategies
}

\author{
Seyed Hossein Fazeli \\ Department of English Language Teaching, Abadan Branch, Islamic Azad University, Iran \\ E-mail: fazeli78@yahoo.com
}

Received: Nov. 23, 2011 Accepted: November 28, 2011 Published: December 31, 2011

doi:10.5296/ijl.v3i1.1106 URL: http://dx.doi.org/10.5296/ijl.v3i1.1106

\begin{abstract}
The present study aims to find out the relationship between the Conscientiousness trait and English Language Learning Strategies (ELLSs) for learners of English as a foreign language. Four instruments were used, which were Persian adapted Strategy Inventory for Language Learning (SILL), A Background Questionnaire, NEO-Five Factors Inventory (NEO-FFI), and Test of English as a Foreign Language (TOEFL). Two hundred and thirteen Iranian female university level learners of English language as a university major in Iran, were volunteer to participate in this research work. The intact classes were chosen. The results show that there is a significant relationship between the Conscientiousness trait and use of the each of six categories of ELLSs.
\end{abstract}

Keywords: Language learning strategies, English learning strategies, English learning, Personality traits, Conscientiousness trait 


\section{Introduction}

Research on the related literature of Language Learning Strategies (LLSs) shows that LLSs has a history of only thirty years that is much sporadic (Chamot, 2005). Recently such strategies have been the focus of specific research (Oxford, 1990), and much of the research was descriptive. Such studies show that in order to affect changes in perceptions of the learners' role in learning process; we need to discover more about what learners do to learn language successfully.

The LLSs have potential to be "an extremely powerful learning tool" (O'Malley, Chamot, Stewner-Manzanares, Kupper, \& Russo 1985, p.43), and in junction with other techniques may well prove to be an extremely useful tool for learners' language learning (Griffiths, 2004). Moreover, use of LLSs help learners store and retrieve material, and facilitate their learning, and the frequency and range of strategy use is the main difference between effective learners and less effective learners (Chomat, Barnhardt, El-Dinary \&Rabbins, 1999).

Marti'nez (1996) discusses some features of LLSs that are inferred from the literature: a) They play important role to facilitate language learning; b) Learners may use LLSs as problem-solving mechanisms to deal with the process of second/foreign language learning. In addition, Oxford (1990) discusses that there are some other features for LLSs such as "problem orientation, ability to support learning directly or indirectly" (p.11).

\section{Review of the Literature}

Since 1990s, there has been growing interest on how personality correlates to the academic performance. In such case, it was shown that successful language learners choose strategies to suit their personalities (Oxford \& Nyikos, 1989), and since LLSs are not innate but learnable (Oxford, 1994), broad justifications have been offered for the evaluation of personality traits as predictors of LLSs. For instance, behavior tendencies reflected in personality traits affect some habits, which influence LLSs (Paunonen \& O'Connor, 2007).

The past studies regarding the relationship between personality and LLSs have contributed to a voluminous archive of evidence pointing to conclusion that to understand scientifically, it must be interesting in personality (cook, 2008). In such case, so high progress has been made toward a consensus on personality structure (Costa \& McCare, 1992; John, 1990; McCare \& John, 1992). For example, it was found that the Conscientiousness trait was associated with deep and achieving learning approaches (Chamorro-Premuzie, Furnham \& Lewis 2007), in another study it was showed that the Conscientiousness trait could be as a predicator of learning performance $(\mathrm{Hu}, 2004)$, even it was indicated that academic performance was correlated with the conscientiousness trait (Chamorro-Premuzie and Furnham, 2008), and more interesting it is that Shokri, Kadivar, Valizadeh and Sangari (2007) found that the Conscientiousness has a significant positive relationship with deep learning, and a negative relationship with surface learning.

\section{The Relationship between Language Learning Strategies and Personality Traits}

Up to 1970's, language learning was studies merely based on linguistics subfields such as 
syntax, semantics, and pragmatics. Since 1970's psycholinguists started to study individuals' linguistic development based on their psychological development. Such studies came as psycholinguistics theories in the studies of different researchers such as Brown (1973), and Smart (1970). In this way, research on LLSs has been inspired by two closely interwoven disciplines: cognitive psychology and second language acquisition.

There is a general belief that the relationship between personality and second language acquisition is as a two-way process which they modify each other (Ellis, 1985), and there are enough evidences that show personality factors can facilitate acquisition of second language (Ely, 1986; Reiss, 1983; Strong, 1983). In addition, since there is a strong relationship between psychological traits and the way that learners use language strategies (Ehraman \& Oxford, 1990), psychological traits can play the most important role in the field of LLSs. In such situation, Reiss (1983) found there is a significant correlation between successful language learning and the conscientiousness trait. At last but not least, a review of the relevant literature shows that personality traits significantly influence success in learning a second language (Gass \& Selinker, 1994) and personality factors are important in development of linguistic abilities (Ellis, 1985).

\section{Methodology}

\subsection{Participants}

The descriptive statistics are such type of numerical representation of participants (Brown, J. D. 1996). The sample drawn from the population must be representative so as to allow the researchers to make inferences or generalization from sample statistics to population (Maleske, 1995). As Riazi (1999) presents "A question that often plagues the novice the researcher is just how large his sample should been order to conduct an adequate survey or study. There is, of course, no clear-cut answer" (pp.242-243). If sample size is too small, it is difficult to have reliable answer to the research questions. If sample is too large, it is difficulty of doing research. To leave a margin of about $20 \%$ for ineffectual questionnaires slightly bigger numbers were chosen. In this way, initially a total of two hundred and fifty Iranian female university level learners of English language as a university major at the Islamic Azad University Branches of three cities which named Abadan, Dezful ,and Masjed-Solyman in Khuzestan province in south of Iran, were asked to participate in this research work. It must bear in mind that number of participants may affect the appropriateness of particular tool (Cohen \& Scott, 1996). The intact classes were chosen.

The chosen participants for this study were female students studying in third grade (year) of English major of B. A. degree, ranging age from 19 to 28(Mean=23.4, SD=2). Their mother tongue was Persian (Farsi) which is the official language of Iran, according to Act 15 of the Iranian constitution.

The socio-economic status of participants, such as the participants' social background, and parents' level education were controlled as well by a questionnaire . Based on some indicators such as the parents' socio-educational background and occupation, the participants were matched as closely as possible for socio-economic background to minimize the effect of 
social class. Accordingly, the participants were classified as a middle class. Moreover the most of the participants from the Islamic Azad University in Khuzestan province, Iran, have middle-class and similar socio-economic background.

Because of the nature of this work (regarding use of the ELLSs), a general English proficiency test for determining the proficiency level of participants in English was applied in order to minimize the effect of English language proficiency. As Jafarpour (2001) defines "the percent classification of subjects by the experimental test that corresponds to those by the criterion" (pp.32-33) (as cited in Golkar \& Yamini, 2007), top of subjects are 27\% and bottom of subjects are 27\% (Golkar \& Yamini, 2007), the participant whom were classified as intermediate subjects, were asked to participate in the current study.

\subsection{Instrumentation in the Current Study}

Four instruments were used to gather data in the current study. They were:

\subsubsection{Strategy Inventory for Language Learning (SILL)}

As Gould (1981) presents "Taxonomy is always a contentious issue because the world does not come to use in neat little packages" (p.158), and there is not a logical and well-accepted system for describing of strategy (Oxford, 1994). In this way, finding a particular classification of LLSs as a universal basic classification which can be as a LLSs' complete classification system, what everybody agrees upon, is impossible. However, from point of view of extensive review of the literature, Oxford (1990) gathered extensive literature on LLSs.

There are many significant differences between Oxford's taxonomy and the other ones. For example, firstly, Oxford classifies heterogeneous strategies into more specific categories (Ehrman, Leaver \& Oxford, 2003); secondly according to O'Malley and Chamot (1990), Oxford's strategy classification is an inclusion of every strategy that has up to then been cited in the learning literature; and thirdly Oxford's taxonomy links individual strategies and groups of strategies with each of the four language skills (Oxford \& Burry-Stock, 1995). In this way, Griffiths (2004) suggests Oxford' classification system of LLSs can be as a useful base for understanding LLSs.

Oxford's taxonomy includes Memory Strategies, Cognitive Strategies, Compensation Strategies, Metacognitive Strategies, Affective Strategies, and Social Strategies.

Based on the Oxford's classification Strategy Inventory for Language Learning (SILL, version 7.0) was developed. SILL is a kind of self-report questionnaire that has been used extensively by researchers in many countries, and its reliability has been checked in multiple ways, and has been reported as high validity, reliability and utility (Oxford, 1996).

The SILL is a structured survey (Oxford, 1990), which according to Oxford and Nyikos (1989) the strategies which were included in the SILL were gathered from extensive literature review. In addition, Oxford (1996) claims in general, SILL reliability has been high, and the reliability remains "very acceptable" (Oxford \& Bury-Stock, 1995, p.6). Moreover, Green and Oxford (1995) claim that reliability using Cronbach's alpha ranging from .93 to .95 
depending whether the survey is taken in learner's own language or in target language. In addition, SILL has used with learners whose native languages were different languages such as Chinese, French, Germen, Italian, Japanese, Korean, Spanish, Thai, and Turkish (Oxford, 1990), and its reliability reported in many studies as high reliability in translated version of different languages (Grainger, 1997; Griffiths, 2002; Oxford \& Nyikos, 1989; Park, 1997; Sharp, 2008; Szu-Hsin, Ting-Hui \& Tzu-Ying, 2006; Yang ,2007).

Regarding validity of SILL, Oxford and Burry-Stock (1995) claim that the all types of validity are very high. In addition, factor analysis of SILL is confirmed by many studies (Hsiao \& Oxford, 2002; Oxford, 1996; Oxford \& Burry-Stock, 1995).In this way, as Ellis (1994) believes, Oxford's taxonomy is possibly the most comprehensive currently available. Several empirical studies have been found moderate intercorrelation between the items of six categories in SILL (Oxford \& Ehrman, 1995).

The original version of SILL includes 50 items, but the adapted version includes 49 items which adapted for the current study. In adapted version of SILL, one item was taken out. The item was deleted based on the feedback from participants in the pilot study. Revision in part of Cognitive Strategies includes deletion of item number 22 "I try not to translate word for word". The possible reason why the item 22 affects the reliability of the SILL can be the suggestion of the most teachers to "avoid translation word for word".

\subsubsection{Test of English as a Foreign Language (TOEFL)}

TOEFL (Structure and Written Expression, and Reading Comprehension parts) as a general English proficiency test was used.

\subsubsection{A Background Questionnaire}

The socio-economic status of participants was controlled as well by a background questionnaire.

\subsubsection{NEO-Five Factors Inventory (NEO-FFI)}

The evidences indicate that five factors of personality is fairly stable over time (Costa \& McCare, 1988; Digman, 1989). In addition, factor structure resembling such factors of personality were identified in numerous sets of variables (Digman \& Inouye, 1986; Goldberg, 1981, 1990; John, 1990; McCare \& Costa, 1985; Saucier \& Goldberg, 1996). Based on such five factors, NEO-FFI was developed. It is a self-scoring, and paper and pencil survey.

The short form of NEO-FFI (Costa \& McCare, 1992) was translated into Persian language (Fathi-Ashtiani, 2009) which was used in the current study. It consists of sixty items, 12 items for each of the "Big Five" sub-scales.

The Conscientiousness trait is one of the five traits which is assessed through NEO-FFI. The Conscientiousness trait represents the tendency to responsible, organized, hard-working, dependable, able to plan, organized, persistent, achievement oriented, purposeful, strong-willed, determined, thinking before acting, delaying gratification, following norms and rules, planning, organizing, prioritizing tasks; and "Conscientiousness describes socially 
prescribed impulse control that facilitate task- and goal-directed behavior" (John \& Srivastava, 1999, p30).

\subsection{Sample of the Pilot Study}

The sample for the pilot study, as "A small-scale replica and a rehearsal of the main study" (Riazi, 1999, p.198), was selected so as it represents the entire sample for participants whom asked to participate in the main study. Since sample size in pilot study ranges from 20 to bigger of 65(Hinkin,1998), thirty nine female students university level learners of English language as a university major at Islamic Azad University Branches of three cities which named Abadan, Dezful , and Masjed-Solyman ,were asked to participate in the pilot study.

\subsection{Reliability of the Instruments}

This section will explore the reliability of the four instruments: SILL, NEO-FFI, the Conscientiousness trait as a sub-scale of NEO-FFI, and TOEFL. Since Cronbach's alpha is one of the standard ways of expressing a test's reliability (Foster, 1998); and its coefficient is commonly used to describe the reliability factors of multi-point formatted questionnaires or scales; in such way, the reliability of our experimental measures were assessed by calculating Cronbach's alpha over the items of the four instruments across all the participants in the current study which were found .89 for SILL(Cronbach's alpha were .73 for Memory Strategies, .71 for Cognitive Strategies, .72 for Compensation Strategies, .81 for Metacognitive Strategies, .71 for Affective Strategies, and .73 for Social Strategies), .82 for NEO-FFI, .80 for the Conscientiousness trait, and .80 for TOEFL. The reliability coefficient indicated the degree to which the results on a scale can be considered internally consistent, or reliable (De Vellis, 2003; Ghiasvand, 2008; Moemeni, 2007; Nunnally \& Bernstein, 1994). Such finding of reliabilities for the four instruments confirm the finding of reliabilities in the pilot study.

\subsection{Data Collection Procedures in the Main Study}

The data for the study described in this study was collected between September 2010 and November 2010 in Iran, at the Islamic Azad University Branches of three cities that are named Abadan, Dezful, and Masjed-Solyman. As stated these three cities are located in Khuzestan province in south of Iran. The period of time to administrate each of stages was assigned based on the pilot study.

\subsubsection{Stage One}

At this stage, the participants were asked to answer TOEFL test. Approximately 80 minutes were taken to answer the test (The first week).

\subsubsection{Stage Two}

At the second stage, the respondents were asked to fill the adapted SILL. The respondents were asked to respond to the questions within 10-15 minutes. Alongside adapted SILL, Background Questionnaire was administrated (The second week).

\subsubsection{Stage Three}


At this stage, NEO-FFI was administrated. 10 - 15 minutes was enough to complete NEO-FFI (The third week).

\subsection{Data Analysis}

After data collection, the data was entered onto databases (Excel and SPSS) to enable data analysis to be carried out.

The procedure of data analysis includes Pearson Correlation that used to identify the strength and direction of the relationship between variables. As known to the researchers in the field, correlation does not imply causality, but it does provide a picture of relationships. The important point, the classification of strength of correlation is not well accepted among different researchers, and there are different classifications such as the classification suggested by Cohen, J. (1988), Delavar (2010), and Ghiasvand (2008). In the current study, the classification that was suggested by Cohen, J. (1988) was chosen as a criterion to interpret and discuss about the strength of the correlation. It is as Table 1:

Table1. The classification was suggested by Cohen, J (1988)

\begin{tabular}{|l|l|}
\hline Level of Strength & $\begin{array}{l}\text { Amount of the } \\
\text { Strength }\end{array}$ \\
\hline Low & r=.10 to .29 \\
\hline Medium & r=.30 to .49 \\
\hline Strong & r= 50 to 1 \\
\hline
\end{tabular}

\section{Results, Discussion, and Conclusion}

In reporting the frequency use of LLSs, Oxford's key (1990) was used to understand mean scores on SILL in the current study.

In the entire sample ( $\mathrm{N}=213$ ), except the Metacognitive category, the mean score for each of the five categories fell in the range of medium strategy use. The strategies in the Metacognitive category were the most frequently used, with a mean of 3.7( $\mathrm{SD}=.64)$. The mean use of strategies in the other five categories were 3.2 $(\mathrm{SD}=.63)$ for Compensation Strategies, 3.1( $\mathrm{SD}=.69)$ for Affective Strategies, 3.1 $(\mathrm{SD}=.79)$ for Social Strategies, 3.0 $(\mathrm{SD}=.59)$ for Memory Strategies, and 3.0 $(\mathrm{SD}=.52)$ for Cognitive Strategies. Mean of the overall strategy use was $3.2(\mathrm{SD}=.45)$, which categorized as a medium level. Except the Metacognitive category, there was not much difference in the mean scores of strategy use among the other five categories.

The means were calculated in order to determine the mean of each of five traits of personality among the total group of the respondents $(\mathrm{N}=213)$ (Table 2). 
Table 2. Means and Standard Deviations (SD) of the five traits of personality in the current study

\begin{tabular}{|l|l|l|l|}
\hline Personality Trait & N & Mean & SD \\
\hline Neuroticism & 213 & 23.0 & 8.3 \\
\hline Extraversion & 213 & 27.4 & 5.5 \\
\hline Openness to Experiences & 213 & 27.9 & 4.7 \\
\hline Agreeableness & 213 & 32.4 & 5.4 \\
\hline Conscientiousness & 213 & 34.7 & 6.3 \\
\hline
\end{tabular}

Table 2 showed that the mean of the Conscientiousness trait (Mean=34.7, SD =6.3) was more than each of the means of the other four traits, and the mean of the Neuroticism trait (Mean=23.0, $\mathrm{SD}=8.3$ ) was less than each of the means of the other four traits.

The Pearson Correlation was performed for all the overall six categories of strategy use and the Conscientiousness trait (Table 3).

Table 3. The summary of correlations among the overall six categories of strategy use and the Conscientiousness trait

\begin{tabular}{|c|c|c|c|c|c|c|c|}
\hline & & $\begin{array}{l}\text { MEM. } \\
\text { S. }\end{array}$ & $\begin{array}{l}\text { COG. } \\
\text { S. }\end{array}$ & $\begin{array}{l}\text { COM. } \\
\text { S. }\end{array}$ & $\begin{array}{l}\text { MET. } \\
\text { S. }\end{array}$ & $\begin{array}{l}\text { AFF. } \\
\text { S. }\end{array}$ & $\begin{array}{l}\text { SOC. } \\
\text { S. }\end{array}$ \\
\hline & $\begin{array}{l}\text { Pearson } \\
\text { Correlation }\end{array}$ & $304^{* *}$ & $199^{* * *}$ & $.190^{* *}$ & $.372^{* *}$ & $.214^{* *}$ & $.256^{* *}$ \\
\hline Conscientiousness & $\begin{array}{l}\text { Sig. } \\
\text { (2-tailed) }\end{array}$ & .000 & .003 & .005 & .000 & .002 & .000 \\
\hline & $\mathbf{N}$ & 213 & 213 & 213 & 213 & 213 & 213 \\
\hline
\end{tabular}

**. Correlation is significant at the 0.01 level (2-tailed).

Mem. S.: Memory Strategies, Cog. S.: Cognitive Strategies, Com. S.: Compensation Strategies, Met. S.: Metacognitive Strategies, Aff. S.: Affective Strategies, Soc. S.: Social Strategies

According to Table 3, regarding the Conscientiousness trait, the students' overall strategy use was significant positively correlated with each of them at the $\mathrm{p}<.01$ level (2-tailed). The levels of correlation were found low (except the correlation between each of Memory, or Metacognitive overall strategy use and the Conscientiousness trait that was at medium level. 
Table 3 indicated that based on increasing of the Conscientiousness level of the students, higher average of Memory Strategies would be used, and based on decreasing of the Conscientiousness trait level, lower average of Memory Strategies would be used. In such way, Table 3 showed that there was a meaningful significant positive relationship between the overall Memory strategy use and the Conscientiousness trait $(r=.304, p<.01)$. The positive relationship implies that the more Conscious students use Memory Strategies more.

Table 3 presented that based on increasing of the Conscientiousness trait level of the students, higher average of Cognitive Strategies would be used, and based on decreasing of the Conscientiousness trait level, lower average of Cognitive Strategies would be used. In such way, Table 3 showed that there was a meaningful significant positive relationship between the overall Cognitive strategy use and the Conscientiousness trait $(r=.199, p<.01)$. The positive relationship implies that the more Conscious students use Cognitive Strategies more.

Table 3 laid out that based on increasing of the Conscientiousness trait level of the students, higher average of Compensation Strategies would be used, and based on decreasing of the Conscientiousness trait level, lower average of Compensation Strategies would be used. In such way, Table 3 showed that there was a meaningful significant positive relationship between the overall Compensation strategy use and the Conscientiousness trait $(r=.190$, $\mathrm{p}<.01)$. The positive relationship implies that the more Conscious students use Compensation Strategies more.

Table 3 represented that based on increasing of the Conscientiousness trait level of the students, higher average of Metacognitive Strategies would be used, and based on decreasing of the Conscientiousness trait level, lower average of Metacognitive Strategies would be used. In such way, Table 3 showed that there was a meaningful significant positive relationship between the overall Metacognitive strategy use and the Conscientiousness trait $(r=.372$, $\mathrm{p}<.01)$. The positive relationship implies that the more Conscious students use Metacognitive Strategies more.

Table 3 indicated that based on increasing of the Conscientiousness trait level of the students, higher average of Affective Strategies would be used, and based on decreasing of the Conscientiousness trait level, lower average of Affective Strategies would be used. In such way, Table 3 showed that there was a meaningful significant positive relationship between the overall Affective strategy use and the Conscientiousness trait $(\mathrm{r}=.214, \mathrm{p}<.01)$. The positive relationship implies that the more Agreeable students use Affective Strategies more.

Table 3 indicated that based on increasing of the Conscientiousness trait level of the students, higher average of Social Strategies would be used, and based on decreasing of the Conscientiousness trait level, lower average of Social Strategies would be used. In such way, Table 3 showed that there was a meaningful significant positive relationship between the overall Social strategy use and the Conscientiousness trait $(\mathrm{r}=.256, \mathrm{p}<.01)$. The positive relationship implies that the more Conscious students use Social Strategies more.

\section{Limitations of the Current Study}

Like any study, several of limitations to the methodology in this study are ones common in 
the literature. Firstly, the need for a large scale since the present study includes small-scale study.

Secondly, it is exclusive reliance on self-report responses to the questionnaires. Since the questionnaire is a self-report and single source of information in this study, it is not clear whether the participants actively used the strategies they indicated and personality that they have. Their response may not be just their beliefs and thoughts that they have about their use of strategies and their personality. In order to investigate students' actual use of strategies, researcher must observe classes, use think-aloud procedure (introspection), interview, and so forth. Moreover, there may also have been some unclear points in questionnaires themselves. In addition, the vagueness of wording has been another persistent problem in using questionnaire (Gu, Wen \& Wu, 1995). Another difficulty in cross-language research involves translation. In the case of SILL, SILL does not describe in detail the LLSs a student uses in responses to any specific language task.

The third one, there is an issue in the statistical procedures. The reliability estimates internal consistency may not be appropriate to measure something that could fluctuate in short period. The test-retest reliability measure is better indicator of reliability in this type of research.

The fourth issue, since measurements which are developed in the western countries may not be so successfully employed in the eastern countries like Iran, and many value measurements which are developed in western countries were not success to assess in eastern countries (Matthews, 2000; Schwartz, Malech, Lehmann, Burgess, Harris \& Owens, 2001). In the case of used instruments, may some limitations disappeared. Such limitations are characteristics of cross cultural- research and instruments.

Generally speaking, it is rarely possible to adequately control for all variables in any natural research, in this way it is better that it should be some research method to corroborate the results of SILL and NEO-FFI.

\section{References}

Brown, J. D. (1996). Testing in language programs. Upper Saddle River, NJ: Prentice Hall Regents.

Brwon, H. D. (1973). Affecting variables in second language acquisition. Language Learning, 23 (2), 231-244. http://dx.doi.org/10.1111/j.1467-1770.1973.tb00658.x

Chamorro-Premuzie, T., \& Furnham, A. (2008). Personality, intelligence and approaches to learning as predictors of academic performance. Journal of Personality and Individual Differences, 44, 1596-1603. http://dx.doi.org/10.1016/j.paid.2008.01.003

Chamorro-Premuzie, T., Furnham, A., \& Lewis, M. (2007). Personality and approaches to learning predict preference for different teaching method. Learning and Individual Differences, 17,241-250. http://dx.doi.org/10.1016/j.lindif.2006.12.001

Chamot, A. U. (2005).Language learning strategy instruction: Current issues and research. Annual Review of Applied Linguistics, 25, 112-130. 
http://dx.doi.org/10.1017/S0267190505000061

Chamot, A. U., Barnhardt, S., El-Dinnary, P. B., \& Rubbins, J. (1999). The learning strategies handbook. New York: Longman.

Cohen, A.D., \& Scott, K. (1996). A synthesis of approaches to assessing language learning strategies. In R. L. Oxford (Ed.), Language learning strategies around the world : cross cultural perspectives (pp. 89-106). Honolulu : University of Hawai'i , Second Language Teaching \& Curriculum Center.

Cohen, J. (1988). Statistical power analysis for the behavioral sciences $\left(2^{\text {nd }}\right.$ ed.). Hillsdale, NJ: Lawrence Erlbaum Associates.

Cook, V. (2008). Second language learning and language teaching ( $4^{\text {th }}$ ed.). London: Edward Arnold.

Costa, P.T., \& McCare, R.R.(1988). Personality in adulthood: A six-year longitudinal study of self-reports and spouse ratings on the NEO personality inventory. Journal of Personality and Social Psychology, 54(4), 853-863.

Costa, P.T., \& McCare, R.R.(1992). Professional Manual for the NEO-PI-R and NEO-FFI. Odessa, FL: Psychological Assessment Resources. http://dx.doi.org/10.1037/0022-3514.54.5.853

De Vellis, R. F. (2003). Scale development: Theory and application ( $2^{\text {nd }}$ ed.). Thousand Oaks, California: Sage.

Delavar, A. (2010). Theoretical and experimental principle of research in human sciences. Tehran: Roshd Publication.

Digman, J. M. (1989). Five robust traits dimensions: Development, stability, and utility. Journal of Personality, 57(1), 195-214. http://dx.doi.org/10.1111/j.1467-6494.1989.tb00480.x

Digman, J. M., \& Inouye, J. (1986). Further specification of the five robust factors of personality. Journal of Personality and Social Psychology, 50,116-123. http://dx.doi.org/10.1037/0022-3514.50.1.116

Ehrman, M., \& Oxford, R. L. (1990). Adult language learning styles and strategies in an intensive training setting. The Modern Language Journal, 74(3), 311-327. http://dx.doi.org/10.1111/j.1540-4781.1990.tb01069.x

Ehrman, M.E., Leaver, B. L., \& Oxford, R. L. (2003). A brief overview of individual differences in second language learning. System, 31, 313-330. http://dx.doi.org/10.1016/S0346-251X(03)00045-9

Ellis, R. (1985). Understanding second language acquisition. Oxford: Oxford University Press.

Ellis, R. (1994).The study of second language acquisition. Oxford: Oxford University Press.

Ely, C. M. (1986). An analysis of discomfort, risk taking, sociability, and motivation in the L2 
classroom.

Language

Learning,

$36(1)$

$1-25$.

http://dx.doi.org/10.1111/j.1467-1770.1986.tb00366.x

Fathi-Ashtiani, A. (2009). Psychological tests: Personality and mental health. Tehran: Be'sat Publication Institute.

Foster, J. J. (1998). Data analysis using SPSS for window: A beginner's guide. Thousand, Oaks, California: Sage Publications.

Gass, S., \& Selinker, L.(1994). Second language acquisition: An introductory course. Hillsdale, NJ: Lawrence Erlbaum.

Ghiasvand, A. (2008). Application of statistics and SPSS in data analysis. Tehran: Lovieh publication.

Goldberg, L. R. (1981). Language and individual differences: The search for universals in personality lexicons. In L. Wheeler(Ed.), Review of personality and social psychology( Vol.2, pp.141-165). Beverrly Hills, CA: Sage.

Goldberg, L. R. (1990). An alternative description of personality: The big five factor structure.

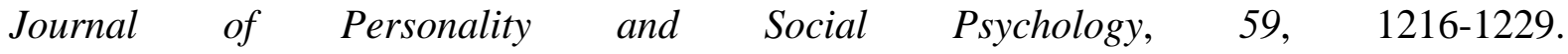
http://dx.doi.org/10.1037/0022-3514.59.6.1216

Golkar, M., \& Yamini, M. (2007). Vocabulary, proficiency and reading comprehension. The Reading Matrix, 7(3), 88-112.

Gould, S. J. (1981). The mismeasure of man. New York: Norton.

Grainger, P. R. (1997). Language-learning strategies for learners of Japanese: investigating ethnicity. Foreign Language Annals, 30(3), 378-385. http://dx.doi.org/10.1111/j.1944-9720.1997.tb02360.x

Green, J. M., \& Oxford, R. L. (1995). A closer look at learning strategies, L2 proficiency, and gender. TESOL Quarterly, 29(2), 261-297. http://dx.doi.org/10.2307/3587625

Griffiths, C. (2002). Using reading as a strategy for teaching and learning language. Paper presented at the International Conference on First and Second Literacy Strategies (College Park, MD, November 1-2, 2002). [Online] Available: http://www.eric.ed.gov/ERICDocs/data/ericdocs2sq1/content_storage_01/0000019b/80/1b/50/ aa.pdf (March 20, 2010)

Griffiths, C. (2004). Language learning strategies: Theory and research. Occasional Paper (1). [Online] Available: http://www.crie.org.nz/research_paper/c_griffiths_op1.pdf (March 12, 2010)

Gu, P. Y., Wen, Q., \& Wu, D. (1995). How often is Often? Reference ambiguities of the likert-scale in language learning strategy research. Occasional Papers in English Language Teaching vol.5. ELT Unit, Chinese University of Hong Kong, 19-35.

Hinkin, T. R. (1998). A brief tutorial on the development of measures for use in survey 
questionnaires. Organizational Research Methods, 1(1), 104-121. http://dx.doi.org/10.1177/109442819800100106

Hsiao, T-Y., \& Oxford, R. L. (2002). Comparing theories of language learning strategies: A confirmatory factor analysis. Modern Language Journal, 86(3), 368-383. http://dx.doi.org/10.1111/1540-4781.00155

Hu, M. L.(2004).The relationship between big five personality traits, learning motivation and learning performance of the hospitality students in taiwan.2004 Asia Pacific Tourism Association (APTA) Conference. [Online] Available: http://www.ntnu.edu.tw/acad/docmeet/a8/a802.doc (March 20, 2010)

John, O. P. (1990). The big five factor taxonomy: dimensions of personality in the nature language and in the questionnaire. In L.A. Pervin(Ed.), Handbook of personality: Theory and research (pp.66-100). New York: Guilford Press.

John, O. P., \& Srivastava, S. (1999). The big five taxonomy: History, measurement and theoretical perspectives. In L.A. Pervin \& O. P. John(Eds.), Handbook of personality: Theory and research . New York: Guilford. [Online] Available: http://pages.uoregon.edu/sanjay/pubs/bigfive.pdf (March 16, 2010)

Maleske, R. T. (1995). Foundations for gathering and interpreting behavior data. Pacific Grove, C. A: Brooks/Cole Publishing Company.

Marti'nez, I. M. P. (1996). The importance of language learning strategies in foreign language teaching. Cuadernos de Filologia Inglesa, 5(1), 103-120. [Online] Available: http://dialnet.unirioja.es/servlet/fichero_articulo?codigo=1325566\&orden=0 (March 16, 2010)

Matthews, B. M. (2000). The Chinese value survey: An interpretation of value scales and consideration of some preliminary results. International Educational Journal, 11(2), 117-126.

McCare, R.R., \& Costa, P.T. Jr. (1985). Updating Norman's adequate taxonomy: Intelligence and personality dimensions in natural language and in questionnaires. Journal of Personality and Psychology, 49,710-721. http://dx.doi.org/10.1037/0022-3514.49.3.710

McCare, R.R., \& John, O. P. (1992). An introduction to the Five-Factor Model and its $\begin{array}{llll}\text { application. Journal of Personality, } & 60(2), & \text { 175-215. }\end{array}$ http://dx.doi.org/10.1111/j.1467-6494.1992.tb00970.x

Moemeni, M. (2007). Statistical analysis with SPSS. Tehran: Ketab neo Publication.

Nunnally, J. C., \& Bernstein, I. H. (1994). Psychometric theory (3 ${ }^{\text {rd }}$ ed.). New York: McGraw-Hill.

Nyikos, M., \& Oxford, R. L. (1993). A factor analytic study of language learning strategy use: Interpretations from information-processing theory and social psychology. Modern Language Journal, 77, 11-22. http://dx.doi.org/10.1111/j.1540-4781.1993.tb01940.x

O'Malley, J. M., \& Chamot, A. U. (1990). Learning strategies in second language acquisition. 
Cambridge : Cambridge University Press.

O'Mally, J. M., Chamot, A. U., Stewner-Manzanares, G., Kupper, L., \& Russo, R. P. (1985). Learning strategies used by beginning and intermediate ESL students. Language Learning, 35(1), 21-46. http://dx.doi.org/10.1111/j.1467-1770.1985.tb01013.x

Oxford, R. L. (1990). Language learning strategies: What every teacher should know. Boston :Heinle \& Heinle.

Oxford, R. L. (1994).Language learning strategies: An update. Online Resources: Digest. [Online] Available: http://www.cal.org/resources/digest/oxford01.html (March 8, 2010)

Oxford, R. L. (1996). Employing a questionnaire to assess the use of language learning strategies. Applied Language Learning, 7(1\& 2), 25-45.

Oxford, R. L., \& Nyikos, M. (1989). Variables affecting choice of language learning strategies by university students. Modern Language Journal, 73(3), 291-300. http://dx.doi.org/10.1111/j.1540-4781.1989.tb06367.x

Oxford, R. L., \& Burry-Stock, J. (1995). Assessing the use of language learning strategies worldwide with the ESL/EFL version of the Strategy Inventory for Language Learning (SILL). System, 23(1), 1-23. http://dx.doi.org/10.1016/0346-251X(94)00047-A

Oxford, R. L., \& Ehrman, M. (1995). Adult's language learning strategies in an intensive foreign language program in the United States. System, 23(3), 359-386. http://dx.doi.org/10.1016/0346-251X(95)00023-D

Park, G. (1997). Language learning strategies and English proficiency in Korean university students. Foreign Language Annals, 30,211-221. http://dx.doi.org/10.1111/j.1944-9720.1997.tb02343.x

Paunonen, S. V., \& O'Connor, M. C.(2007). Big Five personality predictors of post-secondary academic performance. Personality and Individual Differences, 43,971-990. http://dx.doi.org/10.1016/j.paid.2007.03.017

Reiss, M.A. (1983). Helping the unsuccessful language learner. Canadian Modern Language Review, 39(2), 257-266.

Riazi, A.M.(1999). A dictionary of research methods: Quantitative and qualitative. Tehran: Rahnama Publications.

Saucier, G., \& Goldberg, L. R. (1996). Evidence for the Big Five in analyses of familiar English personality adjectives. European Journal of Personality, 7, 1-17.

Schwartz, S. H., Malech, G., Lehmann, A., Burgess, S., Harris, M., \& Owens, V. (2001). Extending the cross-cultural validity of the theory of basic human values with a different method of measurement. Journal of Cross-Cultural Psychology, 32(5), 519-542. http://dx.doi.org/10.1177/0022022101032005001

Sharp, A. (2008). Personality and second language learning. Asian Social Science, 4(11), 
17-25.

Shokri, O., Kadivar, P., Valizadeh, F., \& Sangari, A. K. (2007). Role of personality traits and learning approaches on a academic achievements of university students. Psychological Research, 9(3\&4), 65-84.

Smart, J.C. (1970). Underachievers and overachievers in intermediate French. Modern Language Journal, 54(6), 415-420.

Strong, M. (1983). Social styles and the second language acquisition of Spanish speaking kindergartners. TEOSL-Quarterly, 17(2), 241-258. http://dx.doi.org/10.2307/3586652

Szu-Hsin, Y., Ting-Hui Y., \& Tzu-Ying, W. (2006). Language learning strategy use of applied foreign language students in $\mathrm{Si}-\mathrm{Hu}$ senior high school. [Online] Available: http://www.shs.edu.tw/works/essay/2007/03/2007032815370457.pdf (March 15, 2010)

Yang, M. N. (2007). Language learning strategies for junior college students in Taiwan: investigating ethnicity and proficiency. Asian EFL Journal, 9(2), 35-57. [Online] Available: http://www.asian-efl-journal.com/June_07_mny.php (March 11, 2010)

\section{Author}

Seyed Hossein Fazeli is pursuing his Ph.D. program in linguistics. He has received his M.A. degree in linguistics. His interest includes Language Learning Strategies. Currently he is as a lecturer at Department of English Language Teaching, Abadan Branch, Islamic Azad University, Iran. 